\title{
Expression and Effects of IL-33 and ST2 in Allergic Bronchial Asthma: IL-33 Induces Eotaxin Production in Lung Fibroblasts
}

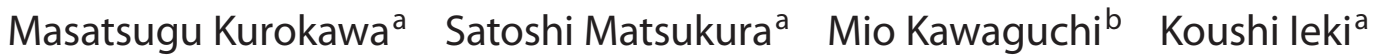 \\ Shintaro Suzuki ${ }^{a}$ Miho Odaka ${ }^{a}$ Shin Watanabe ${ }^{a}$ Tetsuya Homma $^{\text {a }}$ \\ Masayuki Sato ${ }^{a}$ Munehiro Yamaguchi ${ }^{a}$ Hiroko Takeuchi ${ }^{a}$ Mitsuru Adachi ${ }^{a}$ \\ ${ }^{a}$ Division of Respiratory Medicine and Allergology, Department of Internal Medicine, Showa University School of \\ Medicine, Tokyo, and ${ }^{\mathrm{b}}$ Department of Respiratory Medicine, Institute of Clinical Medicine, University of Tsukuba, \\ Ibaraki, Japan
}

\section{Key Words}

IL-33 · ST2 $\cdot$ Bronchial asthma $\cdot$ Fibroblast $\cdot$ Eotaxin/CCL11 • CD11c $\cdot$ Dendritic cell

\begin{abstract}
Background: Interleukin (IL)-33, a new member of the IL-1 cytokine family, has been recognized as a key cytokine that enhances $\mathrm{T}$ helper 2-balanced immune regulation through its receptor ST2; however, the function and relationship of the IL-33 and ST2 pathways in bronchial asthma are still unclear. We investigated the cellular origin and regulation of IL-33 and ST2 in allergic bronchial asthma in vivo and in vitro. Methods: BALB/c mice were sensitized by intraperitoneal injections of ovalbumin (OVA) with alum. Mice were exposed to aerosolized 1\% OVA for $30 \mathrm{~min}$ a day for 7 days. These mice were then challenged with aerosolized 1\% OVA 2 days after the last day of exposure. After the OVA challenge, the mice were sacrificed and their lung tissues were obtained. Mouse lung fibroblasts were cultured and treated with IL-33 or IL-13. Results: The levels of IL-33 mRNA and IL-33 protein in lung tissue increased after the OVA challenge. Most IL-33expressing cells were CD11c+ cells and epithelial cells, and many ST2-expressing cells were stained lung fibroblasts and inflammatory cells. IL-33 induced eotaxin/CCL11 production
\end{abstract}

in lung fibroblasts. IL-33 and IL-13 synergistically induced eotaxin expression. Conclusions: IL-33 may contribute to the induction and maintenance of eosinophilic inflammation in the airways by acting on lung fibroblasts. IL-33 and ST2 may play important roles in allergic bronchial asthma.

Copyright $\odot 2011$ S. Karger AG, Basel

\section{Introduction}

The ST2 gene was originally identified as a gene induced by fibroblasts. It was classified as a member of the interleukin (IL)-1 receptor family [1, 2]. IL-33 was discovered in 2005 as a new member of the IL-1 family [3]. It is a ligand for ST2 [3], which is expressed on the cell surface of mast cells, Thelper (Th) 2 cells, basophils, eosinophils, dendritic cells, and invariant natural killer (NK) T cells [4-15]. IL-1R accessory protein (IL-1RAcP) is required for IL-33-mediated signal transduction [16]. As a cytokine, IL-33 signals by interacting with the receptor complex consisting of membrane-bound ST2 and IL-1RAcP, resulting in NF-kB and MARK activation [17]. This pathway may induce the production of cytokines and chemokines.

\section{KARGER \\ Fax +4161306 1234 \\ E-Mail karger@karger.ch}

www.karger.com
C 2011 S. Karger AG, Basel

$1018-2438 / 11 / 1555-0012 \$ 38.00 / 0$

Accessible online at:

www.karger.com/iaa
Correspondence to: Dr. Masatsugu Kurokawa

Division of Respiratory Medicine and Allergology, Department of Internal Medicine Showa University School of Medicine

1-5-8 Hatanodai, Shinagawa-ku, Tokyo 142-8666 (Japan)

Tel. +8133784 8532, E-Mail cdl94140@ par.odn.ne.jp 
Bronchial asthma is a chronic inflammatory disorder of the airways in which many cells, particularly eosinophils, may play important roles through the release of various mediators. Chronic inflammation may be associated with airway hyperresponsiveness (AHR), variable airflow limitation, and respiratory symptoms. A prominent pathophysiological feature of asthma is airway remodeling with airway inflammation [18-20]. Eosinophil recruitment into airway tissues is a complex mechanism. Chemokines involved in the migration and activation of blood eosinophils, such as eotaxin/CCL11, may be produced by several types of cells including airway fibroblasts that can synthesize and release a variety of proinflammatory and profibrotic cytokines [21-23]. However, the function and relationship of the IL-33 and ST2 pathways in bronchial asthma are still unclear. Eotaxin, a potent chemoattractant for eosinophils, is a critical mediator for the development and prolongation of allergeninduced eosinophilic airway inflammation. We investigated the cellular origin and regulation of IL-33 and ST2 in allergic bronchial asthma in vivo and in vitro.

\section{Animals and Methods}

\section{Animals}

Five-week-old female BALB/c mice were purchased from Sankyo Co., Inc. (Tokyo, Japan). All experiments were performed in accordance with the guidelines for animal experimentation issued by Showa University (Tokyo, Japan).

\section{Antigen Sensitization and Challenges}

The protocol for antigen sensitization and challenge has been described previously $[24,25]$. Mice were actively sensitized by intraperitoneal injection of $50 \mu \mathrm{g}$ ovalbumin (OVA; grade V; Sigma, Tokyo, Japan) with $1 \mathrm{mg}$ alum (Sigma) on days $0,7,14$, and 21 of the experiment. The mice were exposed to aerosolized 1\% OVA (MIPS Co., Inc., Osaka, Japan) for $30 \mathrm{~min}$ on days 28-35 for antigen sensitization and challenged with aerosolized 1\% OVA on day 38 (OVA-challenged mice). After the challenge, they were sacrificed and lung tissue samples were obtained. Control mice were sensitized and challenged with phosphate-buffered saline (PBS).

\section{Real-Time Polymerase Chain Reaction}

Total RNA was extracted from lung tissues and cells using Isogen reagent (Nippon-Gene, Tokyo, Japan). cDNA was synthesized from isolated RNA templates using a high-capacity cDNA archive kit (Applied Biosystems, Tokyo, Japan). The ST2 gene encodes, by alternative splicing, both membrane-bound ST2, which is a receptor for IL-33, and sST2, which is a decoy receptor for IL-33. Therefore, we used TaqMan probe sets of ST2 (membrane-bound ST2), IL-33, and eotaxin/CCL11 (Applied Biosystems). Each probe had a fluorescent receptor dye (FAM) linked to its $5^{\prime}$ end and a downstream quencher dye (TAMURA) linked to its $3^{\prime}$ end. We used TaqMan ribosomal RNA labeled with a fluorescent reporter dye (VIC) as an internal control. Each reaction comprised $25 \mu \mathrm{l}$ of mixture containing $2 \times$ Universal Master Mix (Applied Biosystems), primers, labeled probes, and $500 \mathrm{ng}$ cDNA. Amplification conditions included 40 cycles at $95^{\circ} \mathrm{C}$ for $15 \mathrm{~s}$ and $60^{\circ} \mathrm{C}$ for $1 \mathrm{~min}$ after incubation at $95^{\circ} \mathrm{C}$ for $10 \mathrm{~min}$. Amplification and fluorescence measurements were performed during the elongation step using the ABI PRISM 7700 Sequence Detection System (Applied Biosystems). Data are shown as fold inductions of the control.

\section{Lung Protein}

Lung tissue homogenates were used for the mouse IL-33 and ST2 ELISA kit (R\&D Systems, Minneapolis, Minn., USA). Results were expressed in picograms and normalized with concentrations of albumin [26].

\section{Immunohistochemical Examination}

Lung tissue specimens were fixed in $4 \%$ neutral buffered formalin and embedded in paraffin. The paraffin-embedded specimens were sectioned, and the sections were deparaffinized for 20 min in xylene; they were dehydrated for 5 min each in $100,95,90$, and 70\% ethanol and then washed with PBS for $10 \mathrm{~min}$.

After deparaffinization, the slides were immersed in $10 \mathrm{~mm}$ citric acid buffer ( $\mathrm{pH}$ 6.0) and heated in an autoclave at $121^{\circ} \mathrm{C}$ for $10 \mathrm{~min}$. Endogenous peroxidase activity was blocked by incubation with $0.3 \%$ hydrogen peroxide in methanol for $30 \mathrm{~min}$.

\section{IL-33, ST2, and Vimentin Staining}

Tissue sections were incubated overnight at $4^{\circ} \mathrm{C}$ with goat anti-mouse polyclonal IL-33 antibody, goat anti-mouse polyclonal ST2 antibody, rabbit anti-mouse polyclonal vimentin antibody, or an isotype control (dilution 1:100; Santa Cruz Biotechnology, Santa Cruz, Calif., USA). Secondary antibodies were detected by incubation with Histofine Simple Stain Mouse MAX-PO (goat) reagent or MAX-PO (rabbit) (Nichirei Co., Tokyo, Japan) for 30 min at room temperature. Peroxidase activity was detected with 3-amino-9-ethyl-carbazole solution (Nichirei), and sections were counterstained with Mayer's hematoxylin [24].

\section{Immunohistochemical Staining for IL-33 and CD11c}

Tissue sections were incubated overnight at $4^{\circ} \mathrm{C}$ with rabbit anti-mouse CD11c (Integrin $\alpha \mathrm{X}$ ) and goat anti-mouse IL-33 polyclonal antibody (dilution 1:100; Santa Cruz Biotechnology). Secondary antibodies were detected with Histofine Simple Stain MAX-PO (rabbit and goat, respectively; Nichirei) reagent for 30 min at room temperature. Peroxidase activity was detected with 3-amino-9-ethyl-carbazole solution and 3-diaminobenzedine solution (Nichirei), respectively. Sections were counterstained with hematoxylin [24].

\section{Cell Culture and Treatment}

Mouse lung fibroblasts were purchased from the American Type Culture Collection (No. CCL-206; Manassas, Va., USA) and cultured in Dulbecco's modified Eagle's medium (DMEM; Cellgro, Herndon, Va., USA) with $10 \%$ heat-inactivated fetal bovine serum (FBS; Sigma, St. Louis, Mo., USA), $100 \mathrm{U} / \mathrm{ml}$ penicillin, and $100 \mathrm{ng} / \mathrm{ml}$ streptomycin (Cellgro). They were then incubated with $5 \% \mathrm{CO}_{2}$ at $37^{\circ} \mathrm{C}$. After the media had been replaced, the cells $\left(4 \times 10^{5} \mathrm{cell} / \mathrm{ml}\right)$ were treated with or without either IL-33 or IL13 (R\&D Systems). Total RNA was extracted, and cell supernatants were harvested from the cultures. 
Eotaxin Assay for Culture Supernatant

The levels of eotaxin in the culture supernatant were measured using an ELISA kit (R\&D Systems). Data are presented as picograms of eotaxin per $4 \times 10^{5}$ cells. The minimum detectable dose of mouse eotaxin is $<3 \mathrm{pg} / \mathrm{ml}$.

\section{Statistical Analysis}

Results are expressed as means \pm SE. Significant differences among results were detected using Tukey's test. $\mathrm{p}<0.05$ was considered statistically significant.

\section{Results}

\section{IL-33 Expressions in the Lung}

To identify the function of IL-33 in allergic bronchial asthma, we first investigated IL-33 expression in a murine model of allergic asthma. IL-33 mRNA and proteins in the lung increased after the OVA challenge (fig. la, b).

\section{Immunohistochemical Staining for IL-33}

Red-colored cells indicate IL-33-positive cells. Only the bronchial epithelial cells were positive for IL-33 in the control mice (fig. 2a, b). In addition to bronchial epithelial cells, inflammatory cells were predominately positive for IL-33 six hours after the OVA challenge (fig. 2c, d).

\section{IL-33 and CD11c Expression in the Lung}

To identify the various types of inflammatory cells, we performed double immunohistochemical staining for IL-33 and CD11c. Brown-colored cells were IL-33 and CD11c double-positive cells. Some IL-33-expressing cells were CD11c-positive dendritic cells (fig. 2e).

\section{ST2 Expression in the Lung}

We next investigated ST2 expression in a murine model of allergic asthma. ST2 mRNA and proteins also increased in the lung after the OVA challenge (fig. 3a, b).

Immunohistochemical Staining for ST2 and Vimentin

Only bronchial fibroblasts were weakly positive for ST2 in the control mice (fig. $4 \mathrm{a}-\mathrm{c}$ ). In contrast, bronchial fibroblasts were strongly positive and some infiltrating cells were positive for ST2 six hours after the OVA challenge (fig. $4 \mathrm{~d}-\mathrm{f}$ ). Vimentin is used as a fibroblast marker. Many ST2-expressing cells were stained vimentin-positive fibroblasts.

\section{ST2 Expressions in Mouse Lung Fibroblasts}

Next, we investigated whether ST2 mRNA was expressed in mouse lung fibroblasts. In resting fibroblasts, the polymerase chain reaction (PCR) products were weakly detectable. To investigate whether ST2 expression could be modulated by inflammatory stimuli, fibroblasts were incubated with IL-13. The expression of ST2 mRNA was markedly upregulated by IL-13 at various concentrations (fig. 5).

\section{Effect of IL-33 on Eotaxin Expressions in Mouse Lung} Fibroblasts

We then investigated whether mouse lung fibroblasts could produce eotaxin when stimulated with IL-33. Unstimulated lung fibroblasts expressed eotaxin mRNA at low levels. After stimulation with IL-33, the eotaxin mRNA in lung fibroblasts reached peak levels within $4 \mathrm{~h}$ but gradually decreased within the next $48 \mathrm{~h}$ (data not shown). IL-33-stimulated mouse lung fibroblasts showed significant enhancement of eotaxin mRNA levels compared to unstimulated lung fibroblasts; therefore, eotaxin mRNA expression was upregulated after stimulation with IL-33. The extent of the upregulated expression was dose dependent (fig. 6a). To evaluate whether the production of eotaxin protein accompanied the expression of eotaxin mRNA, we determined the amount of eotaxin in the supernatants of lung fibroblasts. Eotaxin production was expressed as picograms per $4 \times 10^{5}$ cells. Unstimulated lung fibroblasts produced a very small amount of eotaxin. In time course experiments, eotaxin production by IL-33 stimulation continued to increase for at least 48 h (data not shown). Stimulation with IL-33 showed significant enhancement of eotaxin levels compared to unstimulated lung fibroblasts. Upregulation of eotaxin protein expression after stimulation with IL-33 was dose dependent (fig. 6b).

\section{Synergistic Effect of IL-33 and IL-13 on Eotaxin} Expression in Mouse Lung Fibroblasts

The expression of ST2 mRNA in lung fibroblasts was markedly upregulated by IL-13. We also investigated whether mouse lung fibroblasts could produce eotaxin upon stimulation with a combination of IL-33 and IL-13. Stimulation with a combination of IL-33 and IL-13 strongly enhanced eotaxin mRNA levels (fig. 7a). In addition, the cells stimulated by IL-33 and IL-13 produced a dramatic amount of eotaxin (fig. 7b). 

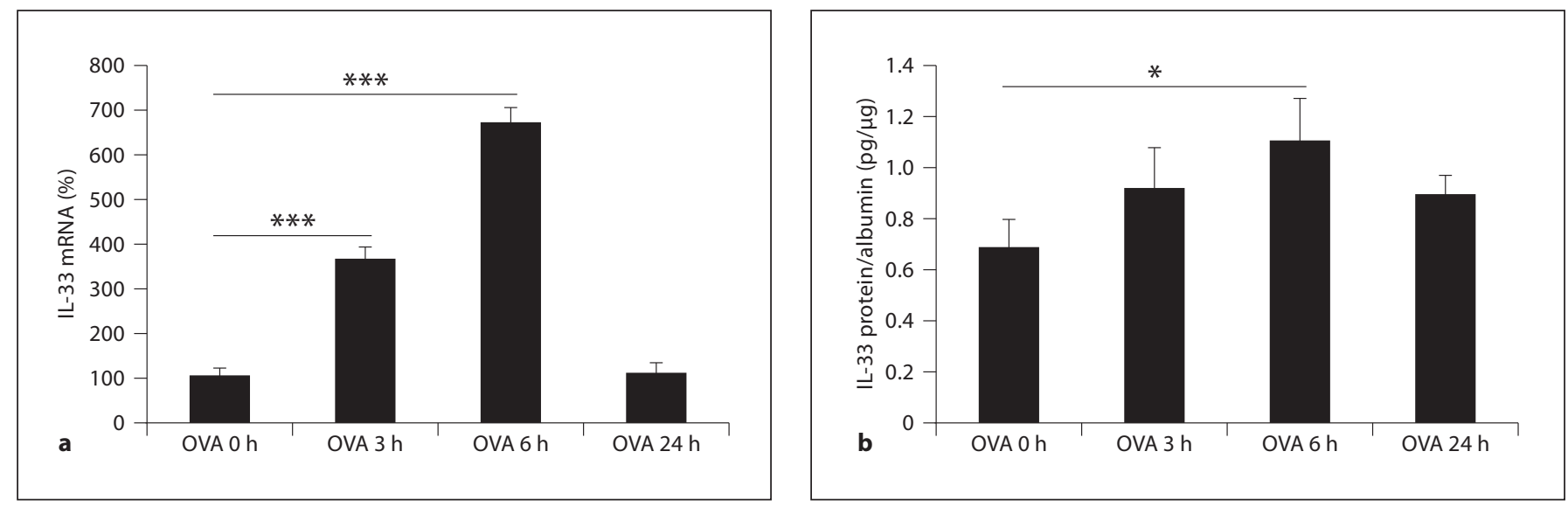

Fig. 1. IL- 33 mRNA and IL-33 protein in lungs. Mice were sensitized and challenged with OVA. a IL-33 mRNA expression in the lungs was determined by real-time PCR. b IL-33 protein concentrations in the lungs were measured by ELISA. Protein levels of homogenized lung tissue were normalized to total lung tissue albumin in order to determine cytokine levels. ${ }^{*} \mathrm{p}<0.05 ;{ }^{* * *} \mathrm{p}<0.001$.
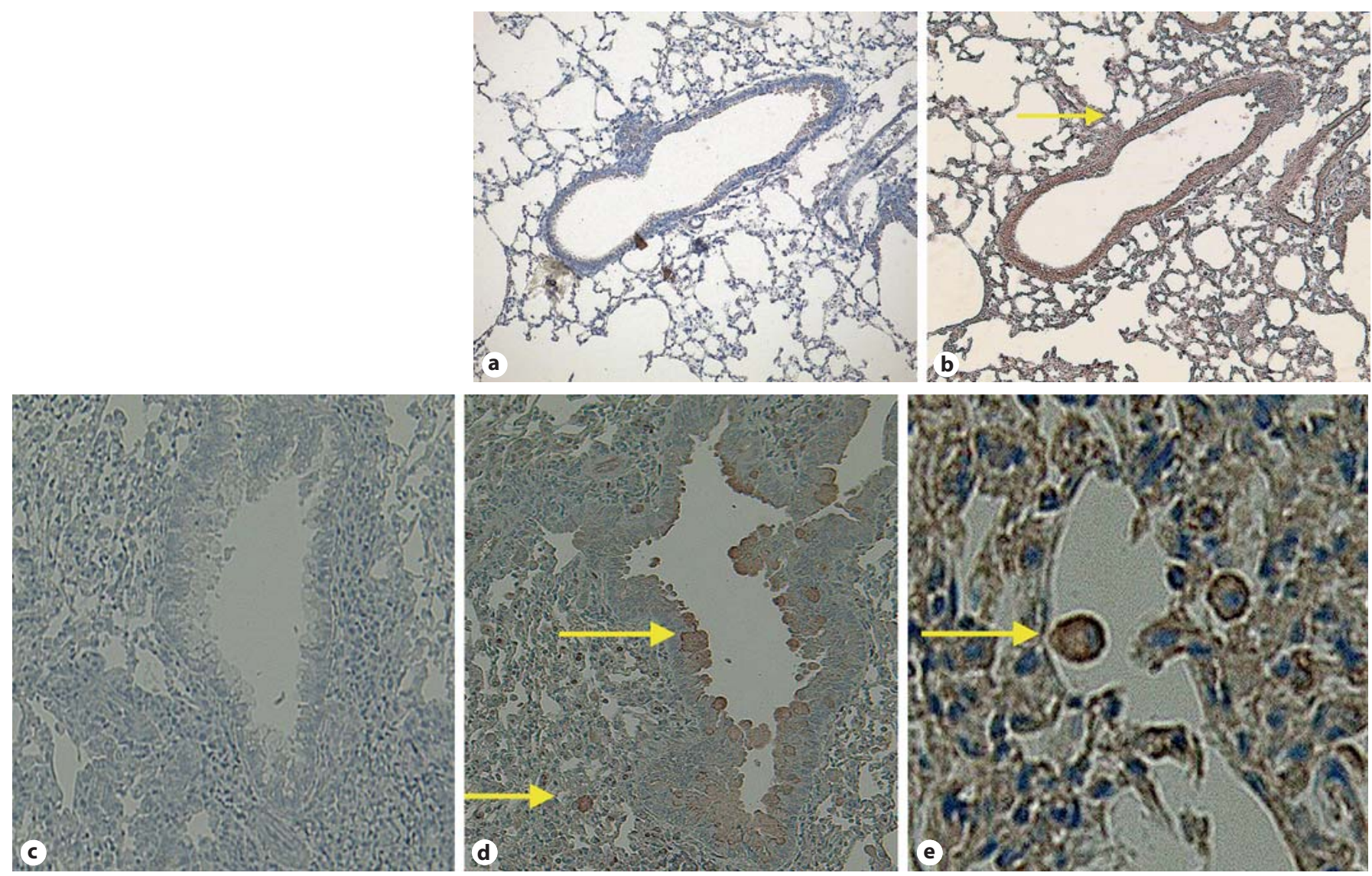

Fig. 2. Immunohistochemical staining for IL-33 in lungs. Immunohistochemical staining was performed using the IL-33 antibody or isotype control. a Control mice isotype. $\mathbf{b}$ Control mice IL-33; the arrow indicates IL-33-positive cells. c OVA-challenged mice isotype. d OVA-challenged mice IL-33; the arrows indicate IL-33-positive cells. e Double mmunohistochemical staining was performed using IL-33 antibody and CD11c antibodies; the arrow indicates IL-33-and CD11c-positive cells.
IL-33 and ST2 in Allergic Bronchial Asthma
Int Arch Allergy Immunol 2011;155(suppl 1):12-20 

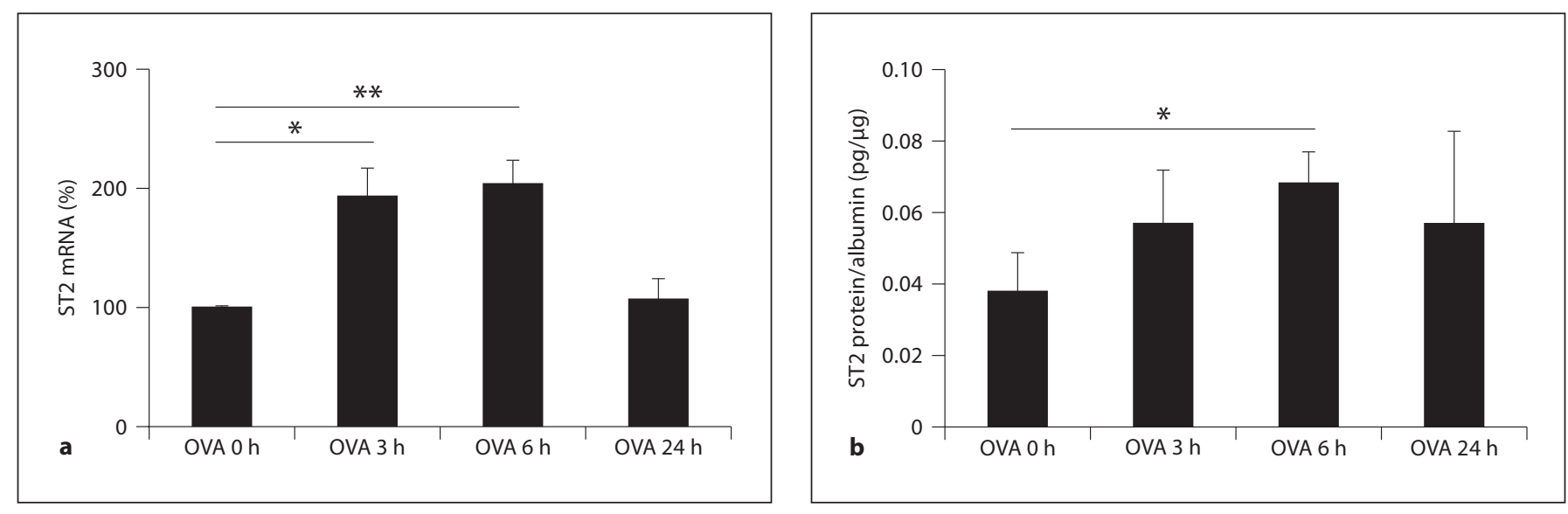

Fig. 3. ST2 mRNA and ST2 protein in lungs. Mice were sensitized and challenged with OVA. a ST2 mRNA expressions in the lungs were determined by real-time PCR. b ST2 protein concentrations in the lungs were measured by ELISA. Protein levels in homogenized lung tissue were normalized to total lung tissue albumin to determine cytokine levels. ${ }^{*} \mathrm{p}<0.05,{ }^{* *} \mathrm{p}<0.01$.
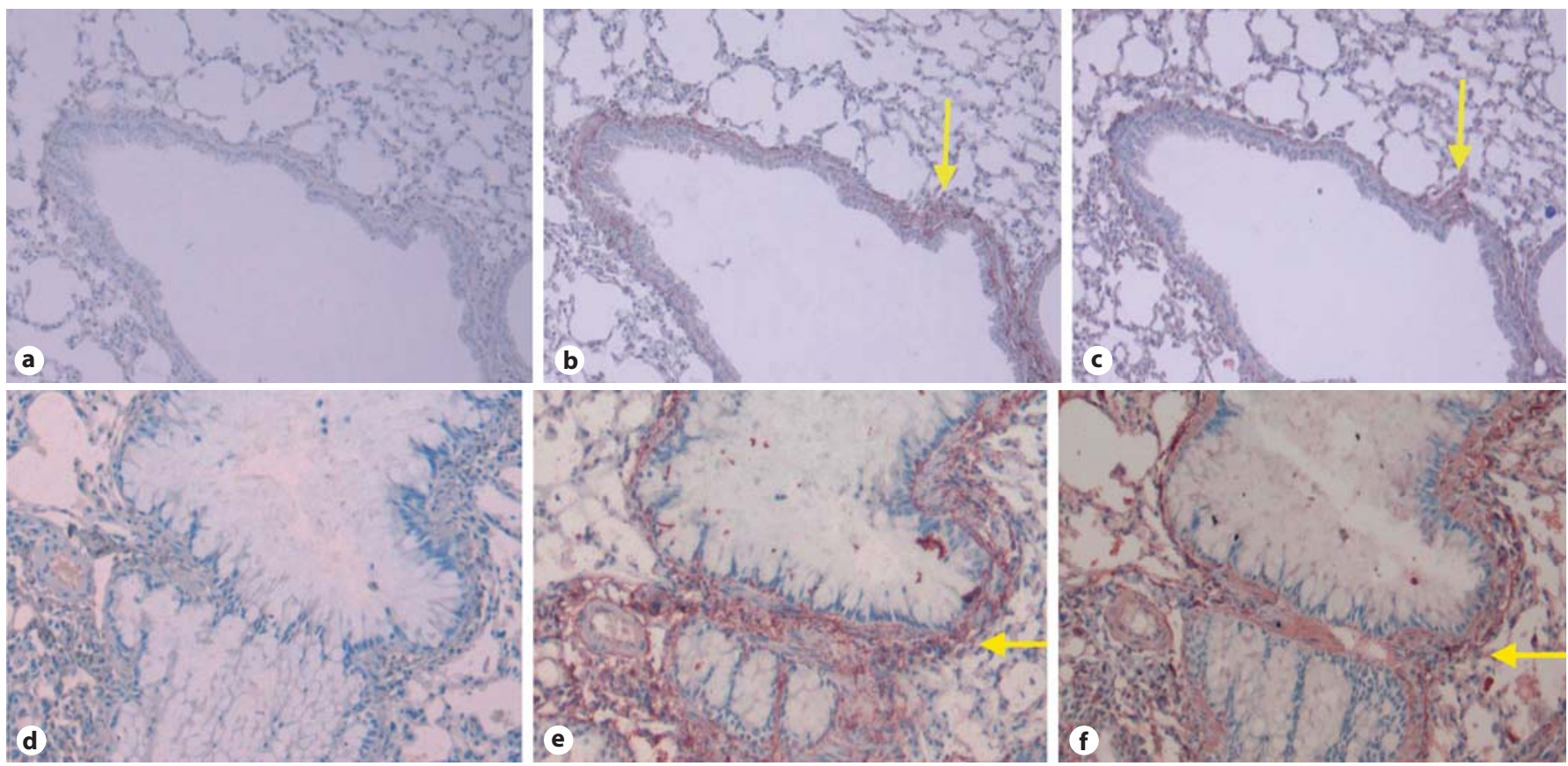

Fig. 4. Immunohistochemical staining for ST2 in lungs. Immunohistochemical staining was performed using the ST2 antibody, vimentin antibody, or isotype control. a Control mice isotype. b Control mice ST2; the arrow indicates ST2-positive cells. c Con-

trol mice vimentin; the arrow indicates vimentin-positive cells. d OVA-challenged mice isotype. e OVA-challenged mice ST2; the arrow indicates ST2-positive cells. f OVA-challenged mice vimentin; the arrow indicates vimentin-positive cells. 
Fig. 5. ST2 expression in mouse lung fibroblasts. ST2 RNA expression in mouse lung fibroblasts was determined by real-time PCR with IL-13 stimulation. ${ }^{* *} \mathrm{p}<0.001$.
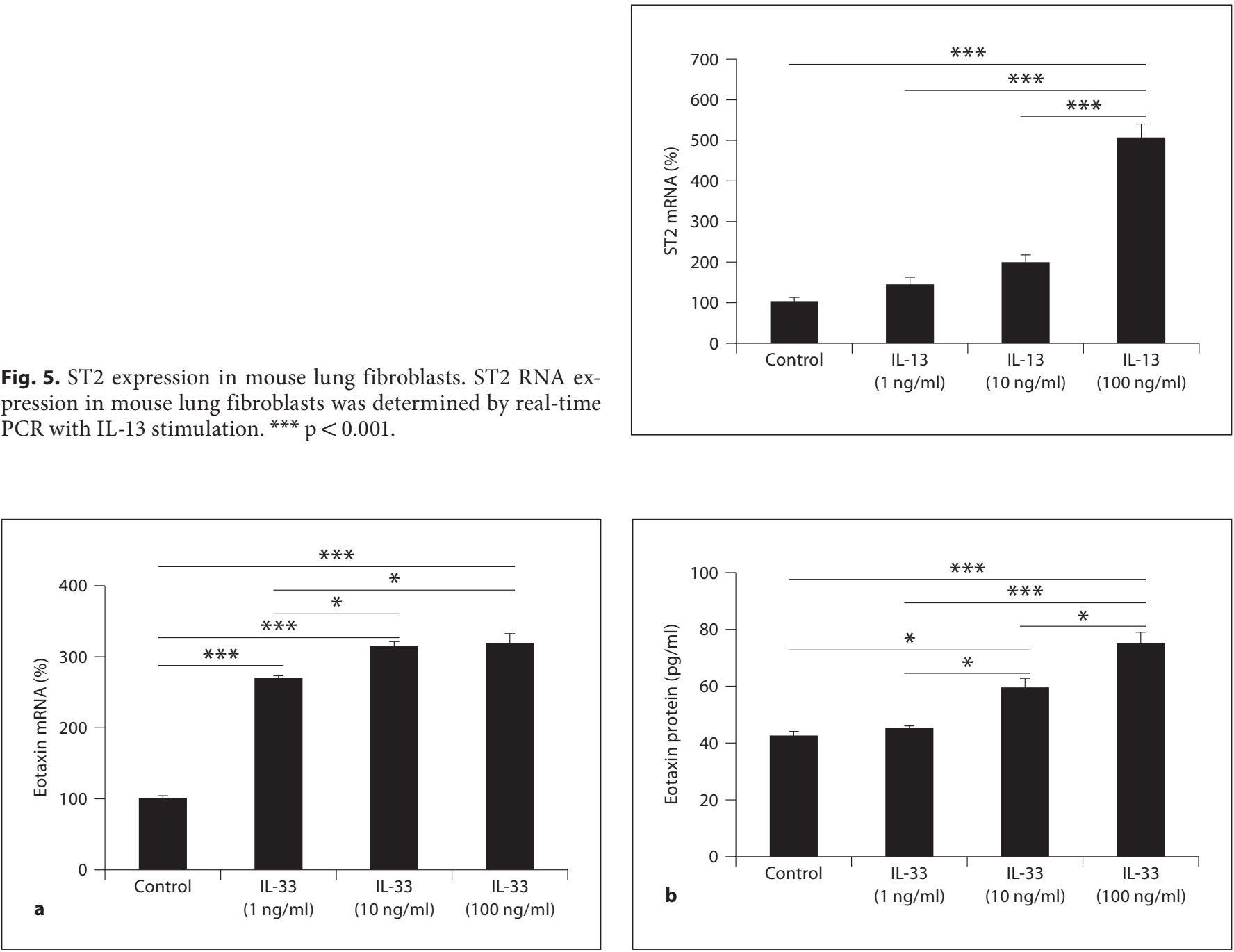

Fig. 6. Eotaxin expression in mouse lung fibroblasts. a Eotaxin RNA expression in mouse lung fibroblasts was determined by real-time PCR. b Eotaxin protein concentrations in supernatants were measured by ELISA with IL-33 stimulation. ${ }^{*} \mathrm{p}<0.05 ;{ }^{* * *} \mathrm{p}<0.001$.

\section{Discussion}

In this study, using a murine model of allergic asthma we demonstrated that IL-33 and ST2 are expressed in lungs after an antigen challenge. IL-33 was constantly expressed in bronchial epithelial cells and its expression was greater in CD11c-positive dendritic cells after the antigen challenge. Previous reports showed that IL-33 is expressed in multiple organs and that the main cell types in which it is expressed are epithelial, endothelial, smooth muscle, fibroblasts, macrophages, and dendritic $[1,3,27,28]$. Prefontaine et al. [29, 30] reported that bronchial epithelium, endothelial cells, and airway smooth muscle cells from asthmatics showed expressed elevated levels of IL-33 compared with those in healthy controls. In addition, Kurowska-Stolarska et al. [28] reported that the morphological appearance of IL-33-positive cells suggested that these might be macrophages, i.e. F4/80+ CCR3- alveolar macrophages, that expressed IL-33 in a murine model of asthma. Schmitz et al. [3] reported that IL-33 mRNA was found in dendritic cells and macrophages; therefore, some IL-33-positive infiltrating cells were dendritic cells and others might have been alveolar macrophages.

In addition, we demonstrated that ST2 is expressed in fibroblasts and some inflammatory cells. Many studies have reported that IL-33 affects various hematopoietic 

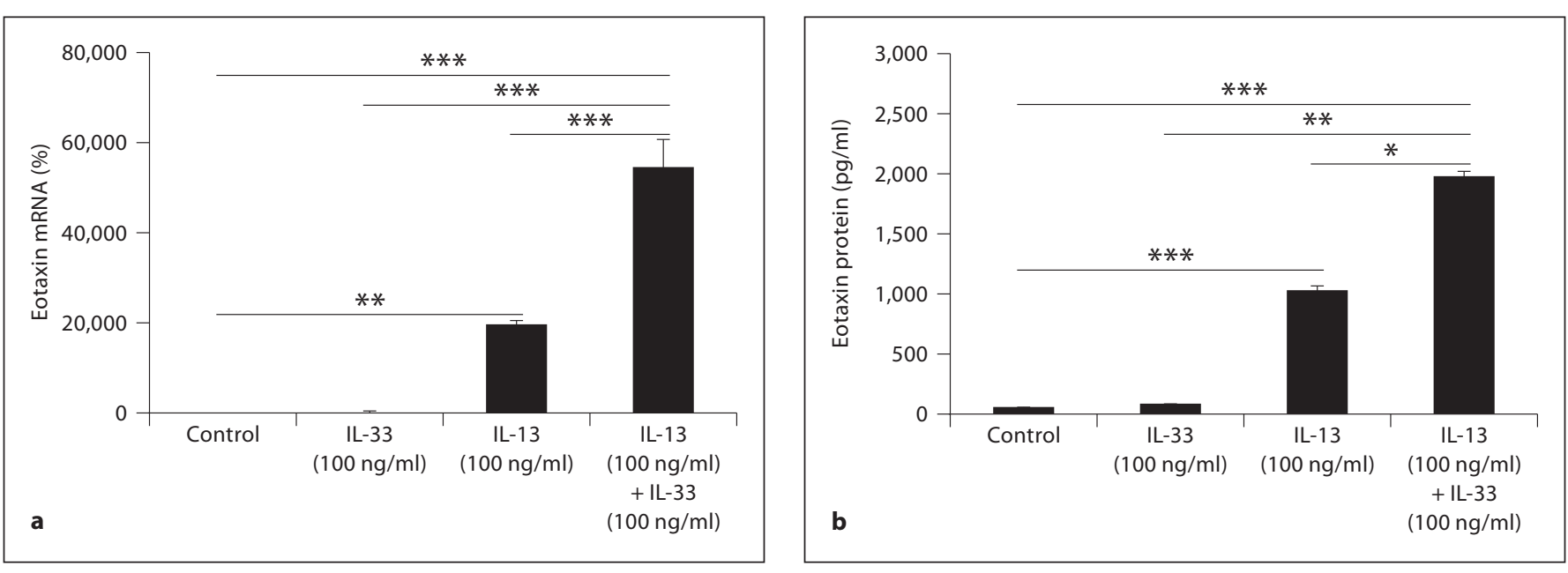

Fig. 7. Eotaxin expression in mouse lung fibroblasts. a Eotaxin RNA expression in mouse lung fibroblasts was determined by real-time PCR. b Eotaxin protein concentrations in supernatants were measured by ELISA with IL-33 or IL-13 alone or in combination with stimulation. ${ }^{*} \mathrm{p}<0.05 ;{ }^{* *} \mathrm{p}<0.01 ;{ }^{* *} \mathrm{p}<0.001$.

cells that express membrane ST2. Treatment of Th2 cells with IL-33 enhanced IL-5 and IL-13 production [7, 8]. Furthermore IL-33 is also a chemoattractant for Th2 cells [31]. It is a potent inducer of proinflammatory cytokine and chemokine production by mast cells. It also induces the degranulation of IgE-primed mast cells and enhances mast-cell maturation and survival [4-6]. Basophils produce several cytokines and chemokines which enhance basophil adhesion, integrin expression, chemotaxis, degranulation, and survival after IL-33 stimulation [10-12]. In addition, IL-33 potently induces eosinophilia, activates eosinophils to produce CXCL8 and superoxide, and upregulates adhesion and survival [12-14]. NKT cells have emerged as potentially important lymphocytes in the context of asthma and airway responsiveness to asthma. IL-33 enhances the production of Th2-type cytokines, including IL-4, and Th1-type cytokines by NK and NKT cells $[7,8]$. Considering the important role of these cells in allergic responses, these findings suggest that IL33 plays an important role in allergies and asthma. Kondo et al. [32] showed that administration of IL-33 to mice ST2/MyD88 dependently induces AHR and goblet cell hyperplasia by inducing IL-4, IL-5, and IL-13 in the lung; however, the same treatment administered to $\mathrm{T}$ and $\mathrm{B}$ cell-deficient RAG2-/- mice, NK cell-deficient mice, and mast cell-deficient $\mathrm{W} / \mathrm{W}^{\mathrm{V}}$ mice could not decrease AHR and eosinophilic infiltration. Therefore, they could not determine the types of innate immune cells that become IL-13-producing cells in response to IL-33 in vivo. Re- cently, however, Moro et al. [33] reported that adipose tissue-associated Lin- c-Kit+ Sca-1+ natural helper cells were a newly identified and distinct population. These cells expressed ST2 and could produce larger amounts of IL-5 and IL-13 in response to IL-33. Yagami et al. [34] reported that ST2 mRNA was expressed in epithelial and endothelial cells. Although they reported that ST2 mRNA was not expressed in normal human lung fibroblasts, the ST2 gene was originally identified as that induced by fibroblasts; therefore, these results might show that ST2 expression is different in fibroblasts cell types.

We showed that, in lung fibroblasts, IL-33 stimulates the production of eotaxin, and we found that IL-13 strongly upregulates ST2 expression. In addition, the combination of IL-33 and IL-13 produces a synergistic and significant increase in eotaxin expression in lung fibroblasts. Eotaxin induces eosinophil migration, degranulation, and differentiation from CD34+ progenitor cells $[21,22,35,36]$, regulates mast cell activation and the migration of mast-cell progenitors into inflamed tissue [37], and plays a role in airway remodeling through recruitment of eosinophils and mast cells, which have profibrogenic activity [23].

Several studies have demonstrated eotaxin expression in lungs affected by bronchial asthma. Gonzalo et al. [38, 39] reported that the main producers of eotaxin mRNA are alveolar epithelial cells in a mouse model with allergic bronchial asthma. Eotaxin is also expressed on smooth muscle cells, lung fibroblasts, T lymphocytes, al-
18

Int Arch Allergy Immunol 2011;155(suppl 1):12-20
Kurokawa et al. 
veolar macrophages, and eosinophils. In addition, lung fibroblasts have been reported to produce eotaxin and are suggested as its major cellular source [40,41]. Because of its ability to upregulate eotaxin expression, IL-33 may thus be involved in the initiation and maintenance of eosinophil infiltration during allergic airway inflammation.

IL-13 significantly enhanced ST2 expression; therefore, the IL-33 and ST2 pathway induced the activation of NF-kB and MAR kinase and the secretion of eotaxin. IL13 was one of the Th2 cytokines that played a prominent role in the pathogenesis of allergic inflammation, and STAT6 was required for IL-13 enhanced expression of ST2 genes [34].
In this study, using a murine model of allergic asthma, we demonstrated that IL-33 and ST2 expression in the lungs is upregulated after an antigen challenge. We suggested that IL-33 and the combination of IL-33 and IL-13 induce a response in lung fibroblasts; therefore, these could enhance eosinophilia in tissues. These results may indicate an important role for IL-33 and ST2 in allergic bronchial asthma.

\section{Disclosure Statement}

The authors declare that no financial or other conflict of interest exists in relation to the content of this article.

\section{References}

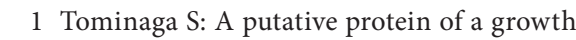
specific cDNA from BALB/c-3T3 cells is highly similar to the extra-cellular portion of mouse interleukin 1 receptor. FEBS Lett 1989;258:301-304.

2 Yanagisawa K, Takagi T, Tsukamoto T, Tetsuka T, Tominaga S: Presence of a novel primary response gene ST2L, encoding a product highly similar to the interleukin 1 receptor type 1. FEBS Lett 1993;318:83-87.

- 3 Schmitz J, Owyang A, Oldham E, Song Y, Murphy E, McClanahan TK, Zurawski G, Moshrefi M, Qin J, Li X, Gorman DM, Bazan JF, Kastelein RA: IL-33, an interleukin-1-like cytokine that signals via the IL-1 receptorrelated protein ST2 and induces T helper type 2-associated cytokines. Immunity 2005;23:479-490.

-4 Moritz DR, Rodewald HR, Gheyselinck J, Klemenz R: The IL-1 receptor-related T 1 antigen is expressed on immature and mature mast cells and on fetal blood mast cell progenitors. J Immunol 1998; 161:4866-4874.

5 Allakhverdi Z, Smith DE, Comeau MR and Delespesse G: The ST2 ligand IL-33 potently activates and drives maturation of human mast cells. J Immunol 2007;179:2051-2054.

-6 Iikura M, Suto H, Kajiwara N, Oboki K, Ohno T, Okayama Y, Saito H, Galli SJ, Nakae S: IL-33 can promote survival, adhesion and cytokine production in human mast cells. Lab Invest 2007;87:971-978.

7 Lohning M, Stroehmann A, CoyleAJ, Grogan JL, Lin S, Gutierrez-Ramos JC, Levinson D, Radbruch A, Kamradt T: T1/ST2 is preferentially expressed on murine Th2 cells, independent of interleukin 4, interleukin5, and interleukin 10, and important for Th2 effector function. Pro Natl Acad Sci USA 1998;95:6930-6935.
-8 Xu D, Chan WL, Leung BP, Hunter D, Schulz K, Carter RW, Mclnnes IB, Robinson JH, Liew FY: Selective expression of a stable cell surface molecule on type 2 but not type 1 helper T cells. J Exp Med 1998;187:787-794.

$\checkmark 9$ Lecart S, Lecoinete N, Subramaniam A, Alkan S, Ni D, Chen R, Boulay V, Pene J, Kuroiwa $\mathrm{K}$, Tominaga $\mathrm{S}$, Yssel $\mathrm{H}$ : Activated, but not resting human Th2 cells, in contrast to Th1 and T regulatory cells, produce soluble ST2 and express low levels of ST2L at the cell surface. Eur J Immunol 2002;32: 2979-2987.

10 Smithgall MD, Comeau MR, Yoon BR, Kaufman D, Armitage R, Smith DE: IL-33 amplifies both Th1- and Th2-type responses through its activity on human basophils, allergen reactive Th2 cells, iNKY and NK cells. Int Immunol 2008;20:1019-1030.

11 Suzukawa M, Iikura M, Koketsu R, Nagase H, Tamura C, Komiya A, Nakae S, Matsushima K, Ohta K, Yamamoto K, Yamaguchi M: An IL-1 cytokine member, IL-33, induces human basophil activation via its ST2 receptor. J Immunol 2008;181:5981-5989.

12 Pecaric-Petkovic T, Didichenko SA, Kaempfer S, Spiegl N, Dahinden CA: Human basophils and eosinophils are the direct target leukocytes of the novel IL-1 family member IL-33. Blood 2009;113:1526-1534.

-13 Cherry WB, Yoon J, Bartmes KR, Iijima K, Kita H: A novel IL-1 family cytokine, IL-33, potently activates human eosinophils. J Allergy Clin Immunol 2008;121:1484-1490.

14 Suzukawa M, Koketsu R, Iikura M, Nakae S, Matsumoto K, Nagase H, Saito H, Matsushima K, Ohta K, Yamamoto K, Yamaguchi M: Interleukin-33 enhances adhesion, CD11b expression and survival in human eosinophils. Lab Invest 2008;88:1245-1253.
15 Rank MA, Kobayashi T, Kozaki H, Bartemes KR, Squilance DL, Kita H: IL-33-activated dendritic cells induce an atypical Th2-type response. J Allergy Clin Immunol 2009;123: 1047-1054.

16 Chackerian AA, Oldham ER, Murphy EE, Schmiz J, Pflanz S, Kastelein RA: IL-1 receptor accessory protein and ST2 comprise the IL-33 receptor complex. J Immunol 2007; 179:2551-2555.

17 Funakoshi-Tago M, Tago K, Hayakawa M, Tominaga S, Ohshio T, Sonoda Y, Kasahara T: TRAF6 is a critical signal transducer in IL-33 signaling pathway. Cell Signal 2008;20: 1679-1686.

18 Busse WW, Lemanske RF Jr: Asthma. N Engl J Med 2001;344:350-362.

19 Wenzel S: Severe asthma in adults. Am J Respir Crit Care Med 2005;111:215-225.

20 Davies DE, Wicks J, Powell RM, Puddicome SM, Holgate ST: Airway remodeling in asthma: new insights. J Allergy Clin Immunol 2003;111:215-225.

21 Garcia-Zepeda EA, Rothenberg ME, Ownbey RT, Celstin J, Leder P, Luster AD: Human eotaxin is a specific chemoattractant for eosinophil cells and provides a new mechanism to explain tissue eosinophilia. Nat Med 1996; 2:449-456.

22 Ponath PD, Qin S, Ringler DJ, Clark-Lewis I, Wang J, Kassam N, Smith H, Shi X, Gonzalo JA, Newman W, Gutierrez-Ramos JC, Mackay CR: Cloning of the human eosinophil chemoattractant, eotaxin: expression, receptor binding, and functional properties suggest a mechanism for the selective recruitment of eosinophils. J Clin Invest 1996;97: 604-612. 
-23 Puxeddu I, Bader R, Piliponsky AM, Reich R, Levi-Schaffer F, Berkman N: The CC chemokine eotaxin/CCL11 has a selective profibrogenic effect on human lung fibroblasts. J Allergy Clin Immunol 2006;117:103-110.

-24 Kurokawa M, Kokubu F, Mastsukura S, Kawaguchi M, Ieki K, Suzuki S, Odaka M, Watanabe S, Takeuchi H, Akabane T, Asano K, Iwase M, Honma I, Adachi M: Effect of corticosteroid on the expression of thymus and activation-regulated chemokine in a murine model of allergic asthma. Int Arch Allergy Immunol 2005;137(suppl 1):60-68.

25 Kurokawa M, Konno S, Mastsukura S, Kawaguchi M, Ieki K, Suzuki S, Odaka M, Watanabe S, Homma T, Sato M, Takeuchi $\mathrm{H}, \mathrm{Hi}-$ rose T, Huang SK, Adachi M: Effect of corticosteroids on osteopontin expression in a murine model of allergic asthma. Int Arch Allergy Immunol 2009;149(suppl 1):7-13.

-26 Durrant DM, Gaffen SL, Riesenfeld EP, Irvin CG, Metzger DW: Development of allergeninduced airway inflammation in the absence of T-bet regulation is dependent of IL-17. J Immunol 2009;183:5293-5300.

27 Moussion C, Ortega N, Girard JP: The IL-1 like cytokine IL-33 is constitutively expressed in the nucleus of endothelial cells and epithelial cells in vivo: a novel 'alarmin'? PLoS One 2008;3:e3331.

28 Kurowska-Stolarska M, Kewin P, Murphy G, Russo RC, Stolarski B, Garcia CC, KomaiKoma M, Pitman N, Li Y, Niedbala W, McKenzie AN, Teixeira MM, Liew FY, Xu D: IL33 induces antigen-specific IL-5+ T cell and promotes allergic-induced airway inflammation independent of IL-4. J Immunol 2008;181:4780-4790.
29 Prefontaine D, Nadigel J, Chouiali F, Audusseau S, Semlali J, Chakir JG, Martin G, Hamid Q: Increased IL-33 expression by epithelial cells in bronchial asthma. J Allergy Clin Immunol 2010;125:752-754.

30 Prefontaine D, Lajoie-Kadoch S, Foley S, Audusseau R, Olivenstein A, Halayko J, Lemiere C, Martin G, Hamid Q: Increased expression of IL-33 in severe asthma: evidence of expression by airway smooth muscle cells. J Immunol 2009; 183:5094-5103.

31 Komai-Koma M, Xu D, Li Y, McKenzie AN, Mclnnes IB, Liew FY: IL-33 is a chemoattractant for human Th2 cells. Eur J Immunol 2007;37:2779-2786.

32 Kondo Y, Yoshimoto T, Yasuda K, FutatsugiYumikura S, Morimoto $M$, Hayashi $N$, Hoshino T, Fujimoto J, Nakanishi K: Administration of IL-33 induces airway hyperresponsiveness and goblet cell hyperplasia in the lungs in the absence of adaptive immune system. Int Immunol 2008;20:791-800.

33 Moro K, Yamada T, Tanabe M, Takeuchi T, Ikawa T, Kawamoto H, Furusawa J, Ohtani M, Fujii H, Koyasu S: Innate production of Th2 cytokines by adipose tissue-associated c-Kit(+)Scal(+) lymphoid cells. Nature 2010; 463:540-544.

34 Yagami A, Kanami O, Morita H, Futamura K, Hashimoto N, Matsumoto K, Saito $\mathrm{H}$, Matsuda A: IL-33 mediates inflammatory responses in human lung tissue cells. J Immunol 2010;185:5743-5750.

35 Fujisawa T, Kato Y, Nagase H, Atsuta J, Terada A, Iguchi K, Kamiya H, Morita Y, Kitaura, Kawasaki M, Yoshie O, Hirai K: Chemokines induce eosinophil degranulation through CCR-3. J Allergy Clin Immunol 2000;106: 507-513.
36 Lamkhioused B, Abdelilah SG, Hamid Q, Mansour N, Delespesse G, Renzi P: The CCR3 receptor is involved in eosinophil differentiation and is upregulated by Th2 cytokines in CD34+ progenitor cells. J Immunol 2003;170:537-547.

37 Price KS, Friend DS, Mellor EA, Jesus N, Watts GF, Boyce J: CC chemokine receptor 3 mobilizes to the surface of human mast cells and potentiates immunoglobulin E-dependent generation of interleukin 13. Am J Respir Cell Mol Biol 2003;28:420-429.

38 Gonzalo JA, Jia GQ, Aguirre V, Friend D, Coyle AJ, Jenkins NA, Lin GS, Katz H, Licht-man A, Copeland N, Kopf M, Gutierrez-Ramos JC: Mouse eotaxin expression parallels eosinophil accumulation during lung allergic inflammation but it is not restricted to a Th2-type response. Immunity 1996;4:1-14.

39 Gonzalo JA, Lloyd CM, Kremer L, Finger E, Martinez-AC, Siegelman MH, Cybulsky M, Gutierrez-Ramos JC: Eosinophil recruitment to the lung in a murine model of allergic inflammation: the role of $\mathrm{T}$ cells, chemokines, and adhesion receptors. J Clin Invest 1996;98:2332-2345.

40 Teran LM, Mochizuki M, Bartels J, Valencia EL, Nakajima T, Hirai K, Schroder JM: Th1and Th2-type cytokines regulate the expression and production of eotaxin and RANTES by human lung fibroblasts. Am J Respir Cell Mol Biol 1999;20:777-786.

41 Sato E, Nelson DK, Koyama S, Hoyt JC, Robbins RA: Inflammatory cytokines modulate eotaxin release by human lung fibroblast cell line. Exp Lung Res 2001;27:173-183. 